\title{
DECREASED SOCIAL CAPITAL IN MARKETING VEGETABLES IN EAST JAVA
}

\author{
Riyanto Sugeng*, Ambayoen Mas Ayu, Hardana Andrean Eka \\ Faculty of Agriculture, University of Brawijaya, Malang, Indonesia \\ *E-mail: suksesbyallah@gmail.com
}

\begin{abstract}
The research objective was to determine the decline in social capital in vegetable marketing in East Java. The method used in this study used a qualitative descriptive approach, namely in-depth interviews (in-depth interviews), participatory observation, and documentation. The results of the study concluded that there had been a decline in social capital in the distribution of vegetables in the eastern part of the region, which could be seen from the first one; there are farmers who no longer keep the agreement with the traders so that the traders have now not started to want to provide capital loans and provide seeds. Second, there are traders who deny the agreement by delaying payment, not paying the debt to the farmers.
\end{abstract}

\section{KEYWORD}

Social capital, vegetables, marketing, farmers.

East Java is one of the barometers of Indonesia's economic development (TribunJatim.com) and has an important role in growing the Indonesian economy. East Java is an Indonesian rice barn (suaramedianasional.com) so East Java is also an Indonesian food agriculture training center. Likewise, East Java horticulture also does not want to be left behind by other regions, East Java has superior vegetable centers that are able to supply vegetables in East Java even in some areas outside East Java. East Java, which is so vast in food, requires traders to distribute agricultural products to Shahyuti (2007). For the role of traders in marketing agricultural products often experience obstacles due to the market of agricultural products in Indonesia in general in the form of imperfect competition markets.

Social capital determines the success of sales of agricultural products. Social capital is a determinant of success because the agricultural market has a unique relationship with the characteristics of mutual cooperation cash. Mutual cooperation is the social capital with the social capital of the trader can grow to be large. Social capital is able to activate togetherness, collective creativity, collective trust, and provide collective benefits (Halil, 2013). Social capital is the main capital for conducting vegetable marketing activities. Social capital as a major component in supporting vegetable marketing in East Java is also supported by Narayana san Prittchett (1997) statement.

Social capital determines the success of sales of agricultural products. Social capital is a determinant of success because the agricultural market has a unique relationship with the characteristics of mutual cooperation cash. Mutual cooperation is the social capital with the social capital of the trader can grow to be large. Social capital can activate togetherness, collective creativity, collective trust, and provide collective benefits (Halil, 2013). Social capital is the main capital for conducting vegetable marketing activities. Social capital as a major component in East Java supporting vegetable marketing is also supported by Narayana san Prittchett (1997) statement.

\section{METHODS OF RESEARCH}

This study uses a qualitative approach, namely the process of extracting data to understand social phenomena based on holistic research, formed by words, and derived from natural situations. In implementing this qualitative approach, it is used to protect the phenomenon of the dynamics of social capital in marketing vegetables in East Java. 


\section{RESULTS AND DISCUSSION}

Farmers Start Not Complying with Agreements with Traders. Some farmers do not comply with agreements with traders. This form of non-compliance is that Farmers do not sell all of their harvested vegetables to traders who give them capital loans and give seeds for free, but there are some that are sold to other traders who buy at high prices. Farmers who are not too naughty, are still a little good by dividing the penny yield by half for traders who buy expensive and $1 / 2$ for those who provide capital. Sometimes farmers are selling most of their crops to traders who buy at a higher price and only a small portion is sold to traders who provide capital. Traders who provide capital loans are only given vegetables that the seller has enough to pay the farmer's debt.

Many reasons conveyed by farmers. Why not comply with the agreement is the seeds die, growth is not good, die during seeding. This is a symptom of reductions that will have an adverse effect on the sustainability of vegetable marketing businesses carried out by traders and also vegetable cultivation by farmers. Though the habits of traders in providing seeds make it increasingly diverse types of vegetables grown by farmers and farmers getting smarter in growing vegetables. providing seed assistance, traders also provide education regarding new types of vegetable commodities. Not only did the traders' habits in providing seedlings to farmers begin to decrease, but the habits of traders in providing loan inputs also began to decrease.

Farmers also began to be dishonest where farmers had begun to mix vegetables with good and bad ones. There are also farmers who dare to sell other traders' vegetables at higher prices even though they already get a down payment / advance from other traders. The feeling of reluctance with traders has decreased. This situation cannot be tolerated because it will increasingly make a gap between farmers and traders who have long had good social relations. Because these few will gradually infect other farmers to do the same with other traders. This decline in social capital occurs if some farmers only use the capital owned by traders and also use traders when the price of vegetables decreases again. The lack of reciprocity of services provided by some farmers to traders has made relations between some farmers and traders less good.

Traders who do not comply with agreements with farmers. Poor behavior carried out by traders also began to arise. Examples of bad behavior are traders who are not on time in making payments to farmers. Farmers face difficulties in taking payment of their crops. This decline in confidence in the accuracy of payments made farmers move away from traders. Farmers away from traders are a big problem where traders cannot get vegetables directly from farmers. This situation makes the profitability of traders also decline. Because by getting vegetables directly from farmers or partnering with farmers, traders will be easy to get vegetable commodities, traders will get more profit difference, and the goods purchased will also be guaranteed quality. The relationship is a form of social capital that provides economic value to traders.

Some merchants are very naughty, very naughty traders usually don't pay their debts to farmers. The reason the trader is losing or stops trading. Usually traders like this cannot borrow vegetables from farmers and other traders. If these traders want to trade again they get different treatment with other traders, where if they are going to buy vegetables from farmers by means of goods there is money. So the trader must immediately pay the cash of the item he bought. Some employers who have received this treatment have difficulty running their businesses. Traders will often lose money. When rare and expensive vegetables such traders will not get vegetables from farmers and other traders and eventually forced to buy on the market. When these traders buy at the market, the price will definitely be more expensive than the farmers. Apart from the more expensive price, another problem is that the quality of goods purchased in the market is not necessarily good, so traders who commit violations will suffer huge losses. So that it can be concluded that traders who commit violations will get strict sanctions. The sanctions are not written in a binding rule, but the sanctions will be very severe if violations are made. This has caused only a few 
traders to violate these rules. Because other traders see traders who violate these rules it is increasingly difficult to trade.

Violations of trade norms will be more difficult in vegetable marketing activities carried out by traders. The difficulty is that trading partners leave the merchant. So the norms and rules are very influential in their trade activities. Norms and beliefs will play a role facilitating or can also inhibit the activities of vegetable marketing businesses carried out by traders.

The decline in social capital is due to the increasing competition so that farmers do not feel dependent on one trader because of their flexibility in choosing traders where farmers will sell their crops. Besides because farmers do not feel dependent on traders, it is also because traders are also getting richer so traders also feel they are not dependent on farmers. In line with Coleman's statement (1993) the feeling of dependency among farmers will decrease due to more wealth.

Changes in Transaction Patterns Due to Decreasing Social Capital. As a result of some changes in the values of social capital, it caused changes in the pattern of transactions between traders and farmers. Traders will choose a system that does not have to be complicated in partnership with farmers. This is because traders have considered farmers to be inconsistent. Traders will choose another system that does not have a social capital relationship that has been very instrumental in the vegetable marketing business they are doing. The following are some of the systems that are chosen by traders in obtaining vegetables:

The slash system is a system by buying vegetables that are still in the paddy field and have not been harvested. This system has actually been around for a long time but is still only done by a few traders. For now, it is a trend of alternative choices that many traders do in getting vegetable commodities. This is the best alternative choice made by traders because it is considered as a simple system, which is unnecessary, convoluted with farmers where at first they have to lend to farmers. But here traders also have to have skills in calculating yields in one stretch.

The underlying reasons for today's traders prefer to cut rather than lend to farmers. This change shows a business system that is commercially oriented and begins to forget about the social capital they have. Going forward if this continues to change increasingly commercially and leave social capital behind, what has happened to this business cannot yet be known to continue or not. If according to the theory of the agricultural market in general it still requires the support of social capital in supporting success in marketing agricultural products.

With the decline in social capital, traders and farmers alike choose safe roads. Farmers if they meet a new trader or a rogue trader, implementing a system has money. Where traders have to pay for the cash vegetables they buy when traders bring vegetables. Whereas in the past traders could pay after the vegetables were sold in the market or term debt. The traders with other traders are big too, treating naughty traders with a system of having money, there is no debt system.

\section{CONCLUSION}

Based on the results of research and data analysis that has been done, the following conclusions are obtained. There has been a decrease in social capital in vegetable trade in East Java where changes in social capital occur in traders and farmers, such changes are; 1. Farmers have begun not to deal with agreements with traders where farmers sell their crops to traders who do not provide loans for capital and seed assistance; farmers also start being dishonest by mixing the results of good penen with poor yields. Traders have started to be dishonest again, padagang colored the time of payment to farmers, there are even traders who run away and do not pay to farmers. Trust between traders also decreases where traders have started to trust in a lot of places where many traders cheat other traders. With this problem, the trading system has finally begun to change where traders buy vegetables with a slash system, then with other traders, with the system there are goods that have money, so they must be paid in full in front. 


\section{REFERENCES}

1. Adena, Rikyanto; Najib, Husain; Harnina, Ridwan. (2012). Communication Strategy of the Southeast Sulawesi Provincial Forestry Service in Relocating Communities Around the Tahura Nipa-Nipa Forest Area in Kendari City

2. B. N. Rasila and M. J. Mudau.(2012). Effective communication as a strategic tool for rural development: A model to take South African Government beyond mobilization and consultation through public participation. Journal of Media and Communication Studies Vol. 4(7), pp. 134-141

3. Burger, K. Kameo, D. \& Sandee, H. (2001). Clustering of Small Agro-Processing Firms in Indonesia. International Food and Agribusiness Management Review, 2(3/4): 289-299.

4. Cangara Hafied. (2013). Communication Planning and Strategy. Jakarta: Rajawali Pers.

5. Caporale, G. M. \& Sova, R. (2015). Trade Flows and Trade Specialisation: The Case of China. Working Paper No. 15-07.

6. Churmen, Imam. (2001). Save sugar industry in Indonesia. Millenium Publisher. Jakarta.

7. Delroy Anthony Armstrong.(2004). The Potential Impact of Trade Policychanges on Caribbean Sugar. B.S., Louisiana State University

8. Effendy, O U. (1990). Communication Studies. Theory and Practice. Bandung: PT Remaja Rosdakarya.

9. Creswell, John W. (2013). Research Design: Qualitative, Quantitative, and Mixed Third Edition approaches. Yogyakarta: Pustaka Pelajar.

10. Haroon Sseguya, Robert Mazur\$, Eric Abbott\$\$ And Frank Matsiko.(2012). Information and Communication for Rural Innovation and Development: Context, Quality and Priorities in Southeast Uganda. Journal of Agricultural Education and Extension. Vol. 18, No. 1, 5570

11. Haley, Stephen.2013. World Raw Sugar Prices The Influence of Brazilian Costs of Production and World Surplus/ Deficit Measures. United States Department of Agriculture

12. Indriyanto. (2010). Forest Ecology. Jakarta: PT Bumi Aksara.

13. Matsumura, Kanichiro.(2010). Demand and Supply Structure for Food in Asia. Sustainability 2011, 3, 363-395; doi:10.3390/su3020363

14. McConnell, Michael ; Erik Dohlman; Stephen Haley. (2010). World Sugar Price Volatility Intensified by Market and Policy Factors

15. McCormick, A. J. Watt, D. A. and Cramer, M. D.(2009). Supply and demand: sink regulation of sugar accumulation in sugarcane. Journal of Experimental Botany, Vol. 60, No. 2, pp. 357-364

16. Mulyana, Deddy. (2001). Introduction to Communication Studies. Penerbit PT Remaja Rosdakarya. Bandung.

17. Peter Walton, Dr Gashaw Kebede (2012). Information and Communication Management Strategy Development

18. Ricardo Ramírez and Wendy Quarry.(2004). Communication Strategies in The Age Of Decentralisation And Privatisation Of Rural Services: Lessons From Two African Experiences. Agricultural Research \& Extension Network

19. Rumánková, Lenka and Smutka, Luboš. (2013). Global Sugar Market - The Analysis Of Factors Influencing Supply and Demand. Volume LXI. No. 2, pp. 463-471

20. Sa'diyah, C. (2014). Factors that influence of economic performance for crystal sugar in Indonesia. (Thesis). Faculty of Agriculture. University of Brawijaya. Malang

21. Sinaga, N. (2006). Model Econometric Aplication. IPB Post Graduate. Bogor.

22. Sugiyono, (2014).Mixed Methods, Bandung: Alfabeta.

23. Susila, Wayan.R dan Bonar M. Sinaga. (2005). Analysis of Sugar Industry Policy in Indonesia. Jurnal Agro - Ekonomi Volume 23 No. 1, page 30-53.

24. Xue Xu and Hailong Xia (2014). Analysis and Outlook of China's Sugar Industry Development. Proceedings of Selected Articles of 2013 World Agricultural Outlook. 